Interview

\title{
Interview with Professor William G. Mayhan, Editor-in-Chief of Med One
}

Med One Editorial Office

16 St Martin's le Grand, London EC1A 4EN, United Kingdom

We are honored to have this interview with Professor William G. Mayhan from Sanford School of Medicine, The University of South Dakota, who is currently serving as Editor-in-Chief of Med One.

\section{INTRODUCTION}

Dr. William G. Mayhan is currently a Professor and the Dean in the Division of Basic Biomedical Sciences at the Sanford School of Medicine at the University of South Dakota. He has been the Chair of Cellular Biology and Anatomy at the LSU Health Sciences Center-Shreveport and the ViceChair for the Department of Cellular and Integrative Physiology at the University of Nebraska Medical Center. His area of expertise is cerebral circulation during health and disease. He has played a leadership role in many societies, has served on numerous study sections and editorial boards, and has had continuous funding for his research from a variety of extramural funding agencies for the past $30+$ years.

\section{INTERVIEW}

\section{Could You Describe to Us Your Current Research Interests?}

Our research examines two aspects of endothelial cell function during disease states, i.e., control of vascular reactivity and permeability of the blood-brain barrier. Our current NIH grant focuses on examining changes in reactivity of cerebral arterioles during exposure to alcohol in utero. In other studies, we are examining the role of cannabinoids in reactivity of cerebral arterioles during type 1 diabetes.

\section{Open Access}

Received: 24 April 2019

Published: 30 April 2019

Copyright (c) 2019 by the author(s). Licensee Hapres, London, United Kingdom. This is an open access article distributed under the terms and conditions of Creative Commons Attribution 4.0 International License.

\section{What Are the Future Directions of Cerebral Circulation Research?}

As with all research areas, I see studies involving the cerebral circulation moving more towards genetic approaches to improve outcome following brain damage/brain injury. Once we understand how cerebral blood flow is controlled at a cellular level, we can then begin to manipulate second messenger systems to improve outcome. However, I believe that we still don't completely understand the regulation of blood flow in the brain and how the blood-brain barrier can be manipulated. So, there are still some very fundamental studies that need to be completed. 


\section{What Has Been Your Most Important Scientific Finding? Your Most} Surprising Finding?

One of the most important contributions that we have made to the scientific community has been related to an understanding of what governs reactivity of cerebral arterioles during disease states. These studies are important because they provided novel information regarding mechanisms that could contribute to the increase incidence of stroke in patients with diseases. So, we have been able to relate important changes in cerebral arterioles to the pathogenesis of stroke.

One of our most surprising findings has been that many disease states "damage" cerebral vessels through very similar pathways. This was surprising to us initially, but it makes sense now.

\section{Could You Tell Us Who the Most Important Person in Your Career Is?}

There are two important people that have shaped my career. Dr. William Joyner was my advisor when I was a graduate student. He nurtured my excitement for discovery. Dr. Donald Heistad served as my mentor when I was a post-doctoral fellow at the University of Iowa. I often call Don my second father. He taught me how to ask questions and how to design my research studies.

\section{Do You Have a Role Model in Science?}

I have a lot of role models in science, mostly colleagues that I have been able to talk to and pass ideas by. Scientists are a community, we listen and we try to help others succeed. I certainly have had the benefit of having many friends that are willing to listen and help me during my career.

\section{Do You Think Serving on Journal Editorial Boards Has Positive Impact on Your Career? If so, How?}

Serving on editorial boards is important for everyone's career. It allows you to be exposed to many aspects of research/science, well beyond your normal boundaries. It opens your mind up to many new techniques and ideas. It also lets others know that you have achieved a level of success that is being recognized by being a part of the journal. This certainly helps with manuscript and grant submissions.

\section{As the Editor-in-Chief of Med One, Where Do You See the Journal in Three or Five Years' Time?}

There is so much competition for publishing your work. It seems as if there are new journals starting up on a daily basis. I probably get between 10-20 requests every day to send original research articles or reviews to various journals. I would like to see Med One become a journal that gains the respect of all scientists and is recognized as a journal that publishes high quality research articles and timely reviews. 


\section{What Actions Need to Be Done to Arrive There?}

We have to convince scientists to submit their manuscripts/reviews to the journal because those articles will be read by a large audience.

\section{What Do You Think Are the Characteristics of a Good Journal?}

Respect and a record of outstanding publications. A good journal must also have an editorial board that is composed of individuals that are respected in their fields of research.

\section{What Would You Say Are the Benefits of “Open Access” Journals?}

Timely publication of information. Ease of access for the scientific community. But, an open access journal needs to be careful and publish only quality work.

\section{Would You Like to Give Some Suggestions to Early Career Researchers?}

Enjoy what you do. We all have had grants and manuscripts rejected for one or more reasons. You have to develop a thick skin and keep moving forward. Some of the best advice that you will get is contained in grants/manuscripts that have been rejected.

\section{What Do You Wish to Say to the Editorial Board Members of Med One?}

Welcome and I hope that together we can build a high-quality, wellrespected journal.

How to cite this article:

Med One Editorial Office. Interview with Professor William G. Mayhan, Editor-in-Chief of Med One. Med One. 2019;4:e190007. https://doi.org/10.20900/mo.20190007 